\title{
IMPLEMENTASI KONSEP GOOD GOVERNANCE DALAM MEWUJUDKAN KESEJAHTERAAN SOSIAL DI DESA LANDUNGSARI KECAMATAN DAU KABUPATEN MALANG
}

\author{
Adam Surya Pramudya, Nurul Zuriah, Rohmad Widodo \\ FKIP Universitas Muhammadiyah Malang, Indonesia \\ Email: Pramudyaadam@gmail.com
}

\begin{abstract}
ABSTRAK
Fenomena KKN timbul dan merabah disegala bidang karena sistem pemerintahannya yang tidak dikelola dengan baik. Salah satu cara agar sistem pemerintahan berjalan dengan baik maka harus ada pengimplementasian konsep good governance dari suatu lembaga pemerintahan.Penelitian ini bertujuan untuk : (1) Mendeskripsikan bagaimana implementasi konsep good governance di Desa Landungsari, (2) Menganalisis faktor pendukung dan penghambat, (3) menjelaskan solusi dalam mengatasi masalah yang dihadapi. Penelitian ini menggunakan teknik penelitian deskriftif kualitatif. Dimana peneliti berusaha memberikan gambaran secara sistematis dan cermat fakta-fakta aktual dan sifat-sifat populasi tertentu. Bertujuan untuk memecahkan masalah-masalah aktual dan mengumpulkan data. Pengumpulan data diperoleh dengan teknik wawancara observasi dan dokumentasi. Adapun informan yang digali informasinya yakni kepala desa, sekretaris desa, tokoh desa, dan warga desa Landungsari kabupaten Malang.Berdasarkan penelitian diperoleh hasil sebagai berikut: (1) konsep good governance telah diimplementasikan oleh pemerintah desa Landungsari (2) Faktor pendukung yaitu kemampuan dan kompetensi pegawai, sedangkan faktor penghambatnya adalah kedisiplinan dari pegawai desa tersebut. (3) solusi dengan membina pegawai dengan baik dan disiplin dan konsistensi.Berdasarkanhasilpenelitian diperoleh kesimpulan sebagai berikut: (1) Implementasi konsep good governanace telah diimplementasikan di desa Landungsari kabupaten Malang, (2) Faktor pendukung yaitu kemmapuan dan kompetensi pegawai Desa. Sedangkan faktor panghambatnya adalah indisipliner dari pegawai desa tersebut, (3) solusi melalui pembinaan pegawai dengan baik dan disiplin dan konsistensi.
\end{abstract}

Kata Kunci : Implementasi, Good Governance, Kesejahteraan Sosial.

\begin{abstract}
The phenomenon of corruption arise and spread in all fields because of the system of government that is not managed properly. One way that the governance system goes well then there should be the implementation of the concept of good governance of a government agency. This research aims to : (1) Describe how the implementation of the concept of good governance in the village Landungsari, (2) Analyzing the supporting factors and obstacles, (3) explain the solution in addressing the problems faced. This research usesdescriptive qualitative research techniques. Where researchers tried to give an idea systematically and meticulously actual facts and the properties of certain populations. Aiming to solve the actual problems and collect data. The data collection was obtained by interview observation and documentation. The information unearthed information that the village head, village secretary, village leaders and villagers Landungsari Malang regency.Based on the research results as follows: (1) the concept of good governance has been implemented by the village government Landungsari, (2) Factors supporting the ability and competence of the employees, while inhibiting factor is the discipline of the employees of the village. (3) solutions to foster employee well and discipline and consistency.Based on the research results obtained the following
\end{abstract}


conclusions: (1) Implementation of the concept of good governance has been implemented in the village of Malang regency Landungsari, (2) Factors supporting the ability and competence of the employees of the village, While inhibiting factor is the indiscipline of the village employees, (3) solutions through employee coaching well and discipline and consistency.

Keywords : Good Governance, social welfare

\section{PENDAHULUAN}

Terjadinya krisis ekonomi di Indonesia antara lain disebabkan oleh tatacarapenyelenggaraan pemerintahan yang tidak dikelola dan diatur dengan baik. Akibatnya timbul berbagai masalah seperti korupsi, kolusi dan nepotisme (KKN) yang sulit diberantas, masalah penegakan hukum yang sulit berjalan, monopoli dalam kegiatan ekonomi, serta kualitas pelayanan kepada masyarakat yang memburuk.

Masalah-masalah tersebut juga telah menghambat proses pemulihan ekonomi Indonesia, sehingga jumlah pengangguran semakin meningkat, jumlah penduduk miskin bertambah, tingkat kesehatan menurun, dan bahkan telah menyebabkan munculnya konflik-konflik di berbagai daerah yang dapat mengancam persatuan dan kesatuan negara Republik Indonesia.

Bahkan kondisi saat ini pun menunjukkan masih berlangsungnya praktek dan perilaku yang bertentangan dengan kaidah tata pemerintahan yang baik, yang bisa menghambat terlaksananya agenda-agenda reformasi.

Penyelenggaraan pemerintahan yang baik adalah landasan bagi pembuatan dan penerapan kebijakan negara yang demokratis dalam era globalisasi. Fenomena demokrasi ditandai dengan menguatnya kontrol masyarakat terhadap penyelenggaraan pemerintahan, sementara fenomena globalisasi ditandai dengan saling ketergantungan antarbangsa, terutama dalam pengelolaan sumber-sumber ekonomi dan aktivitas dunia usaha (bisnis).
Kedua perkembangan di atas, baik demokratisasi maupun globalisasi, menuntut redefinisi peran pelaku-pelaku penyelenggaraan pemerintahan. Pemerintah, yang sebelumnya memegang kuat kendali pemerintahan, cepat atau lambat harus mengalami pergeseran peran dari posisi yang serba mengatur dan mendikte ke posisi sebagai fasilitator. Dunia usaha dan pemilik modal, yang sebelumnya berupaya mengurangi otoritas negara yang dinilai cenderung menghambat perluasan aktivitas bisnis, harus mulai menyadari pentingnya regulasi yang melindungi kepentingan publik. Sebaliknya, masyarakat yang sebelumnya ditempatkan sebagai penerima manfaat (beneficiaries), harus mulai menyadari kedudukannya sebagai pemilik kepentingan yang juga harus berfungsi sebagai pelaku.

Menurut Mardoto (2009:18) untuk mewujudkan konsep good governance dapat dilakukan dengan mencapai keadaan yang baik dan sinergi antara pemerintah, sektor swasta dan masyarakat sipil dalam pengelolaan sumber-sumber alam, sosial, lingkungan dan ekonomi. Prasyarat minimal untuk mencapai good governance adalah adanya transparansi, akuntabilitas, partisipasi, pemberdayaan hukum, efektifitas dan efisiensi, dan keadilan. Kebijakan publik yang dikeluarkan oleh pemerintah harus transparan, efektif dan efisien, serta mampu menjawab ketentuan dasar keadilan. Sebagai bentuk penyelenggaraan negara yang baik maka harus keterlibatan masyarakat di setiap jenjang proses pengambilan keputusan. 
Prinsip-prinsip good governance menurut LAN (2000) terdiri dari prinsip akuntabilitas, prinsip transparansi, prinsip kesetaraan, prinsip supremasi hukum, prinsip keadilan, prinsip partisipasi, prinsip desentralisasi, prinsip kebersamaan, prinsip profesionalisme, prinsip cepat tanggap, prinsip efektif dan efisien, prinsip berdaya saing (Ningsih, Indah, Razak, 2013: 2 ).

Oleh karena itu, tata pemerintahan yang baik perlu segera dilakukan agar segala permasalahan yang timbul dapat segera dipecahkan dan juga proses pemulihan ekonomi dapat dilaksanakan dengan baik dan lancar. Disadari, mewujudkan tata pemerintahan yang baik membutuhkan waktu yang tidak singkat dan juga upaya yang terus menerus. Disamping itu, perlu juga dibangun kesepakatan serta rasa optimis yang tinggi dari seluruh komponen bangsa yang melibatkan tiga pilar berbangsa dan bernegara, yaitu para aparatur negara, pihak swasta dan masyarakat madani untuk menumbuhkembangkan rasa kebersamaan dalam rangka mencapai tata pemerintahan yang baik.

Menurut Prasitejo (2009:6) bahwa good governance merupakan praktek penerapan kewenangan pengelolaan berbagai urusan. penyelenggaraan negara secara politik, ekonomi dan administratif di semua tingkatan. Dalam konsep di atas, ada tiga pilar good governance yang penting, yaitu, Kesejahteraan rakyat (economic governance), Proses pengambilan keputusan (political governance), Tata laksana pelaksanaan kebijakan (administrative governance).

Menurut Effendi (2010:15) good governance menyentuh 3 pihak yaitu pihak pemerintah (penyelenggara negara), pihak korporat atau dunia usaha (penggerak ekonomi), dan masyarakat sipil (menemukan kesesuaiannya). Ketiga pihak tersebut saling berperan dan mempengaruhi dalam penyelenggaraan negara yang baik. Sinkronisasi dan harmonisasi antar pihak tersebut menjadi jawaban besar. Menurut (Sumarto dalam Tampubolon, 2009:1-2) Governance, diartikan sebagai mekanisme, praktik dan tata cara pemerintah dan warga mengatur sumber daya serta memecahkan masalah-masalah publik. Kualitas governance dinilai dari kualitas interaksi yng terjadi antara komponen governance yaitu pemerintah, civil society dan sektor swasta. Lebih lanjut dikatakan Sumarto (2009:17) Istilah good governance saat ini menjadi sangat "trendi". Ada yang menterjemahkan good governance sebagai kepemerintahan yang prima atau tata pemerintahan yang baik.

Sebagai cara untuk mewujudkan kesejahteraan sosial, konsep good governance adalah salah satu cara yang tepat untuk mewujudkan hal tersebut. Sebagai contoh kecilnya pemerintah desa landungsari kecamatan Dau Kabupaten Malang, dalam pengimplementasiannya mencoba mengimplementasikan konsep good governance tersebut.

\section{METODE}

Ditinjau dari jenis datanya, pendekatan yang digunakan dalam penelitian yang berjudul implementasi konsep good governance dalam mewujudkan kesejahteraan sosial di desa Landungsari kecamatan Dau kabupaten Malang ini adalah pendekatan kualitatif. Pendekatan kualitatif adalah prosedur penelitian yang menghasilkan data deskriftif berupa kata-kata tertulis atau lisan dari orang-orang dan perilaku yang dapat diamati (Zuriah, 2009:92).

Penelitian kualitatif memerlukan ketajaman analisis, objektivitas, sistematis,

Adam Surya P, dkk. Implementasi Konsep Good Governance dalam Mewujudkan Kesejahteraan Sosial di Desa Landungsari Kecamatan DAU Kabupaten Malang 
dan sistematik sehingga diperoleh ketepatan dalam interpretasi, sebab hakikat dari suatu fenomena atau gejala penganut penelitian kualitatif adalah totalitas atau gestalt (Zuriah, 2009:92).

Adapun jenis pendekatan penelitian adalah deskriftif, penelitian deskriftif yaitu penelitian yang berusaha untuk menuturkan pemecahan masalah yang ada sekarang berdasarkan data-data.

Jenis penelitian deskriftif kualitatif yang digunakan pada penelitian ini dimaksudkan untuk memperoleh informasi mengenai implementasi konsep good governance dalam mewujudkan kesejahteraan sosial didesa Landungsari Kecamatan Dau Kabupaten Malang. Selain itu dengan pendekatan kualitatif diharapkan dapat diungkapakan situasi dan permasalahan yang benar-benar terjadi dan dihadapi dalam pengiimplementasiannya.

Analisis data dalam penelitian merupakan suatu kegiatan yang sangat penting dan memerlukan ketelitian serta kekritisan dalam penelitian. Imran dalam (Sugiyono, 2016:336), analisis data dalam penelitian kualitatif adalah proses pelacakan dan pengaturan secara sistematis transkip wawancara, catatan lapangan, dan bahanbahan lain yang dikumpulkan untuk meningkatkan pemahaman pada bahanbahan tersebut agar dapat di interpretasikan temuannya kepada orang lain. Dalam hal ini peneliti melakukan pencatatan pada saat wawancara, mengumpulkan data-data dari dokumen yang relevan dengan penelitian berupa foto-foto wawancara dengan Kepala desa beserta staf desa yang bersangkutan, hingga kegiatan selanjutnya yaitu menyusun hasil-hasil wawancara kemudian diketik dan dikembangkan untuk dianalisis sehingga menghasilkan sebuah kesimpulan. Sedangkan observasi dilakukan pada saat peneliti melakukan wawancara, peneliti terlibat langsung dilokasi kemudian mengamati kejadiankejadian di lapangan.

\section{HASIL DAN PEMBAHASAN}

\section{Implemetasi konsep good governance dalam mewujudkan kesejahteraan sosial di desa Landungsari}

Berdasarkan hasil penelitian yang didapatkan oleh peneliti, bahwa implementasi konsep good governance telah diimplementasikan oleh pemerintah desa Landungsari khususnya dalam transparansi atau keterbukaan didalam anggaran desa kepada masyarakat desa Landungsari agar masyarakat mengerti prosesnya. Serta tanggap atau responsif terhadap kebutuhan masyarakat khususnya kebutuhan dasar masyarakat desa seperti HAM dan persamaan hak tanpa terkecuali tanpa ada satu pihak pun yang dikesampingkan.

Bersamaan dengan itu,selaku sekretaris desa Landungsari juga memperkuat dan memiliki pendapat yang sama yang mengatakan sangat penting untuk menerapakan sistem good governance dalam mewujudkan pemerintahan yang baik dan bersih dari penyelewengan dan selalu melibatkan masyarakat melalui wakil-wakilnya dalam membuat peraturan atau kebijakan.

Konsep good governance sangat penting untuk di implementasikan karena berdampak bagus kepada masyarakat dan pemerintah desa itu sendiri. Melalui prinsip dasar good governance yang meliputi transparansi atau keterbukaan dalam anggaran dana desa yang melibatkan wakilwakil desa, lalu ada partisipasi dari masyarakat desa terhadap peraturan atau kebijakan yang dibuat oleh pemerintah desa Landungsari dan responsif terhadap keluhan masyarakat desa di dalam 
persamaan hak untuk menjamin masyarakat desa di dalam ekonomi dan politik agar terciptanya masyarakat desa yang sejahtera.

Berdasarkan hasil observasi dan hasil wawancara dengan informan di atas didapati kondisi pemerintahan desa Landungsari telah menerapkan konsep good governance hal ini diindikasikan dari kesesuaian antara hasil observasi dan wawancara yang menunjukkan bahwa konsep good governance ini benar-benar dijalankan dengan baik oleh pemerintah desa Landungsari. Kondisi ini dilandasi atas apa yang disebut oleh Intitute on Governance sebagai konsep good governance yang memenuhi beberpa hal sebagai berikut: a) Kerangka kerja tim (team work) antarorganisasi, departemen, dan wilayah; b) Hubungan kemitraan antara pemerintah dengan setiap unsur dalam masyarakat negara yang bersangkutan; c) Pemahaman dan komitmen terhadap manfaat dari pentingnya tanggung jawab bersama dan kerjasama dalam suatu keterpaduan serta sinergisme dalam pecapaian tujuan; d) Adanya dukungan dan sistem imbalan yang memadai untuk mendorong terciptanya kemampuan dan keberanian menanggung risiko (risk taking) dan berinisiatif, sepanjang hal ini secara realistis dapat dikembangkan; e) Adanya pelayanan administrasi publik yang berorientasi pada masyarakat, mudah dijangkau masyarakat dan bersahabat, berdasarkan kepada asas pemerataan dan keadilan dalam setiap tindakan dan pelayanan yang diberikan kepada masyarakat, berfokus pada kepentingan masyarakat, bersikap profesional, dan tidak memihak (non partisan).
Faktor pendukung dan penghambat dari implementasi konsep good governance dalam mewujudkan kesejahteraan sosial di desa Landungsari

Berdasarkan hasil penelitian dilapangan yang telah dilakukan pada kepala desa Landungsari kecamatan DAU kabupaten Malang, yang menjadi faktor pendukung dan penghambat konsep good governanvce. Faktor pendukung dari konsep good governance adalah kemampuan atau kompetensi pegawai. Kemampuan atau kompetensi yang dimiliki pegawai mengacu kepada dimensi perilaku dari sebuah perilaku organisasi yang diperlukan seseorang untuk dapat melaksanakan pekerjaannya secara memuaskan. Semakin baik kemampuan atau kompetensi pegawai dalam bekerja maka semakin baik kinerja pegawai dalam memberikan pelayanan.

Sedangkan faktor penghambat dari konsep good governance itu sendiri adalah kedisiplinan. Kedisiplinan merupakan salah satu tolok ukur untuk melihat kinerja aparat pemerintah dalam menjalankan tugas-tugasnya khususnya dalam melayani masyarakat.Kedisiplinan merupakan salah satu tolok ukur untuk melihat kinerja aparat pemerintah dalam menjalankan tugas-tugasnya khususnya dalam melayani masyarakat. Kedisiplinan memegang peranan yang amat penting dalam konsep good governance. Seorang pegawai yang mempunyai tingkat kedisiplinan yang tinggi akan tetap bekerja dengan baik walaupun tanpa diatasi oleh atasan. Seorang pegawai yang disiplin tidak akan mencuri waktu kerja untuk melakukan hal-hal yang tidak ada kaitannya dengan pekerjaan. Namun berdasarkan observasi dan wawancara, 
ditemukan kondisi yang menunjukkan bahwa tingkat kedisiplinan aparatur desa Landungsari yang masih rendah. Umumnya ketrelambatan hadir berkisar 30 menit sampai dengan 1 jam, dan pulang 20 sampai 30 menit lebih awal dibanding dengan jam yang seharusnya. Dan tak jarang juga pegawai desa landungsari tidak hadir di kantor secara periodik.

Solusi untuk mengatasi hambatan yang dihadapi dalam implementasi konsep good governanace dalam mewujudkan kesejahteraan sosial di desa Landungsari

Setiap masalah yang dihadapi pasti dapat diatasi dengan berbagai macam solusi. Begitu pula dengan kendala yang dihadapi oleh hambatan implementasi konsep good governance dalam mewujudkan kesejahteraan sosial di desa Landungsari. Salah satu solusi untuk menghadapi hambatan dalam implementasi good governance dalam mewujudkan kesejahteraan sosial di desa Landungsari adalah dengan jalan memberikan pembinaan pegawai dengan baik adanya peraturan disiplin yang memuat pokokpokok kewajiban, larangan, dan memberikan sanksi apabila terjadi perilaku indisipliner. Dalam rangka usaha untuk mencapai tujuan masyarakat desa yang sejahtera, diperlukan adanya pegawai desa sebagai unsur aparatur desa, abdi desa, dan abdi masyarakat yang penuh kesetiaan dan ketaatan kepada pancasila, UUD 1945, serta bersatu padu, bermental baik, berwibawa, dan menjauhi sifat sifat korupsi untuk menyelenggarakan tugas pemerintahan yang baik didalam pembangunan desa Landungsari. Kemudian yang tidak kalah pengtingnya adalah pemanfaatan waktu yang seefektif mungkin demi terciptanya pelayanan kerja yang maksimal.
Kondisi pemerintahan desa Landungsari telah menerapkan konsep good governance hal ini diindikasikan dari kesesuaian antara hasil observasi dan wawancara yang menunjukkan bahwa konsep good governance ini benar-benar dijalankan dengan baik oleh pemerintah desa Landungsari namun masih terdapat beberapa faktor penghambat yang tentunya diperlukan penyelesaian terhadap permasalahan yang sedang terjadi tersebut. Solusi yang dapat dilakukan dalam pencapaian konsep good governance adalah dengan jalan memberikan pembinaan pegawai dengan baik adanya peraturan disiplin yang memuat pokokpokok kewajiban, larangan, dan memberikan sanksi apabila terjadi perilaku indisipliner. Pendisiplinan terhadap kondisi yang tidak disiplin merupakan hal yang sulit dan perlu dilakukan secara konsisten dan tegas terhadap apa yang sudah dicita-citakan. Dalam rangka usaha untuk mencapai good governance dan masyarakat desa yang sejahtera, diperlukan adanya pegawai desa sebagai unsur aparatur desa, abdi desa, dan abdi masyarakat yang penuh kesetiaan dan ketaatan kepada pancasila, UUD 1945, serta bersatu padu, bermental baik, berwibawa, dan menjauhi sifat sifat korupsi untuk menyelenggarakan tugas pemerintahan yang baik didalam pembangunan desa Landungsari serta menggunakan waktu secara efektif dan efisien.

\section{SIMPULAN}

Berdasarkan hasil penelitian mengacu pada rumusan masalah dan tujuan penelitian tentang implementasi konsep good governance di desa Landungsari kecamatan Dau kabupaten Malang dapat disimpulkan sebagai berikut: 
Kesimpulan dari penelitian ini adalah konsep good governance sangat penting untuk di implementasikan karena berdampak bagus kepada masyarakat dan pemerintah desa itu sendiri. Melalui prinsip dasar good governance yang meliputi transparansi atau keterbukaan dalam anggaran dana desa yang melibatkan wakil-wakil desa, lalu ada partisipasi dari masyarakat desa terhadap peraturan atau kebijakan yang dibuat oleh pemerintah desa Landungsari dan responsif terhadap keluhan masyarakat desa didalam persamaan hak untuk menjamin masyarakat desa didalam ekonomi dan politik agar terciptanya masyarakat desa yang sejahtera. Berdasarkan hasil observasi dan hasil wawancara dengan informan di atas didapati kondisi pemerintahan desa Landungsari telah menerapkan konsep good governance hal ini diindikasikan dari kesesuaian antara hasil observasi dan wawancara yang menunjukkan bahwa konsep good governance ini benar-benar dijalankan dengan baik oleh pemerintah desa Landungsari. Kesimpulan hasil wawancara tersebut adalah bahwa faktor pendukung dari konsep good governance adalah kemampuan atau kompetensi pegawai. Kemampuan atau kompetensi yang dimiliki pegawai mengacu kepada dimensi perilaku dari sebuah perilaku organisasi yang diperlukan seseorang untuk dapat melaksanakan pekerjaannya secara memuaskan. Semakin baik kemampuan atau kompetensi pegawai dalam bekerja maka semakin baik kinerja pegawai dalam memberikan pelayanan. Sedangkan faktor penghambat dari konsep good governance itu sendiri adalah kedisiplinan. Kedisiplinan merupakan salah satu tolok ukur untuk melihat kinerja aparat pemerintah dalam menjalankan tugas-tugasnya khususnya dalam melayani masyarakat.
Berdasarkan hasil penelitian di atas didapati kondisi pemerintahan desa Landungsari telah menerapkan konsep good governance hal ini diindikasikan dari kesesuaian antara hasil observasi dan wawancara yang menunjukkan bahwa konsep good governance ini benar-benar dijalankan dengan baik oleh pemerintah desa Landungsari namun masih terdapat faktor pendukung dan penghambat. Faktor pendukung baik yang teramatai melalui observasi maupun wawancara didapati bahwa pemerintah desa Landungsari sudah memiliki kemampuan atau kompetensi yang seharusnya dimiliki pegawai (good governance) mengacu kepada dimensi perilaku dari sebuah perilaku organisasi yang diperlukan seseorang untuk dapat melaksanakan pekerjaannya secara memuaskan. Pemerintah desa Landungsari pula memiliki kemampuan yang baik dalam bekerja, mengutamakan kualitas dan keteraturan, kesadaran organisasional, mendapatkan pengarahan, mencari informasi, berpikir secara konseptual dan percaya diri dalam bekerja.

Sedangkan faktor penghambat dari konsep good governance itu sendiri adalah kedisiplinan. Kedisiplinan merupakan salah satu tolok ukur untuk melihat kinerja aparat pemerintah dalam menjalankan tugas-tugasnya khususnya dalam melayani masyarakat. Kedisiplinan memegang peranan yang amat penting dalam konsep good governance. Seorang pegawai yang mempunyai tingkat kedisiplinan yang tinggi akan tetap bekerja dengan baik walaupun tanpa diatasi oleh atasan. Seorang pegawai yang disiplin tidak akan mencuri waktu kerja untuk melakukan hal-hal yang tidak ada kaitannya dengan pekerjaan. Namun berdasarkan observasi dan wawancara, ditemukan kondisi yang menunjukkan

Adam Surya P, dkk. Implementasi Konsep Good Governance dalam Mewujudkan Kesejahteraan Sosial di Desa Landungsari Kecamatan DAU Kabupaten Malang 
bahwa tingkat kedisiplinan aparatur desa Landungsari yang masih rendah. Umumnya ketrelambatan hadir berkisar 30 menit sampai dengan 1 jam, dan pulang 20 sampai 30 menit lebih awal dibanding dengan jam yang seharusnya. Dan tak jarang juga pegawai desa landungsari tidak hadir di kantor secara periodik.

Kesimpulan hasil penelitian di atas didapati bahwa salah satu solusi untuk menghadapi hambatan dalam implementasi good governance dalam mewujudkan kesejahteraan sosial di desa Landungsari adalah dengan jalan memberikan pembinaan pegawai dengan baik adanya peraturan disiplin yang memuat pokokpokok kewajiban, larangan, dan memberikan sanksi apabila terjadi perilaku indisipliner. Dalam rangka usaha untuk mencapai tujuan masyarakat desa yang sejahtera, diperlukan adanya pegawai desa sebagai unsur aparatur desa, abdi desa, dan abdi masyarakat yang penuh kesetiaan dan ketaatan kepada pancasila, UUD 1945, serta bersatu padu, bermental baik, berwibawa, dan menjauhi sifat sifat korupsi untuk menyelenggarakan tugas pemerintahan yang baik didalam pembangunan desa Landungsari. Kemudian yang tidak kalah pengtingnya adalah pemanfaatan waktu yang seefektif mungkin demi terciptanya pelayanan kerja yang maksimal.

Solusi lain yang dapat dilakukan dalam pencapaian konsep good governance adalah dengan jalan memberikan pembinaan pegawai dengan baik adanya peraturan disiplin yang memuat pokokpokok kewajiban, larangan, dan memberikan sanksi apabila terjadi perilaku indisipliner. Pendisiplinan terhadap kondisi yang tidak disiplin merupakan hal yang sulit dan perlu dilakukan secara konsisten dan tegas terhadap apa yang sudah dicita- citakan. Dalam rangka usaha untuk mencapai good governance dan masyarakat desa yang sejahtera, diperlukan adanya pegawai desa sebagai unsur aparatur desa, abdi desa, dan abdi masyarakat yang penuh kesetiaan dan ketaatan kepada pancasila, UUD 1945, serta bersatu padu, bermental baik, berwibawa, dan menjauhi sifat sifat korupsi untuk menyelenggarakan tugas pemerintahan yang baik didalam pembangunan desa Landungsari serta menggunakan waktu secara efektif dan efisien.

Berdasarkan pada kesimpulan tersebut diatas, penulis memberikan saran berikut :

\section{Bagi Desa Landungsari}

Mewujudkan terciptanya kondisi pemerintahan yang baik dalam melakukan pelayanan terhadap publik merupakan wujud penting dalam upaya mensejahterakan masyarakat dari elemen keluarga hingga nasional Indonesia secara menyeluruh. Disini peran desa sangat diharapkan hadir di dalamnya sehingga publik dapat menjalankan proses kegiatan baik itu administrasi maupun kebutuhankebutuhan lain yang dapat menunjang kebutuhan masyarakat pada elemen desa. Desa merupakan ujung tombak pemerintah dalam upaya peningkatan kondisi sosial ekonomi hingga budaya masyarakat sehingga diperlukan pemerintahan desa yang memebuhi unsur-unsur good governance.

\section{Bagi masyarakat}

Good governance merupakan kondisi yang baik dalam proses pensejahteraan masyarakat. Good governance menjadi tanggung jawab semua pihak termasuk masyarakat desa, sehingga masyarakat desa perlu dan wajib melakukan pengawalan terhadap perilaku dan proses pemerintahan yang dijalankan oleh 
pemerintah desa, begitu pula di desa Landungsari. Sehingga disarankan masyarakat desa Landungsari untuk peduli dan ikut mengawasi pemerintahan yang dijalankan oleh pemerintah desa Landungsari agar pemerintahan yang benar-benar memenuhi konsep good governance dapat terwujud.

\section{Bagi peneliti selanjutnya}

Penelitian dan penulisan ini diharapkan dapat menjadi salah sarana penambahan khasanah kajian mengenai good governance dalam mewujudkan kesejahteraan sosial serta menambah wawasan politik. Dan pula dapat berguna untuk penelitian yang selanjutnya sebagai sumber referensi dalam penerapan konsep good governance dipemerintah daerah baik pada lingkungan desa atau pada lingkungan pemerintahan yang lebih tinggi.

\section{DAFTAR PUSTAKA}

Effendi. 2005. Membangun Budaya Birokrasi Untuk Good Governance. Makalah Seminar Lokakarya Nasional Reformasi Birokrasi Kantor Menteri Negara PAN.

Mardoto. 2009. Mengkritisi Clean And Good Governance Di Indonesia

Ningsih, dkk. 2013. Jurnal ilmiah Analisis Hubungan Prinsip-prinsip Good Governance dengan Kinerja Pegawai di Dinas Kesehatan Kabupaten Luwu Timur.

Prasetijo. 2009. Good Governance Dan Pembangunan Berkelanjutan

Sugiyono. 2016. Metode penelitian pendidikan pendekatan kuantitatif kualitatif dan $R \& D$, Bandung: Alfabeta
Tampubolon, 2013. Jurnal ilmiah pelaksanaan prinsip good governance dalam alokasi dana desa (ADD) di Desa Teluk Bakau Kecamatan Gunung Kijang Kabupaten Bintan

Zuriah. 2009. Metodologi Penelitian Sosial dan Pendidikan. Jakarta: PT Bumi Aksara

Adam Surya P, dkk. Implementasi Konsep Good Governance dalam Mewujudkan Kesejahteraan Sosial di Desa Landungsari Kecamatan DAU Kabupaten Malang 